means confined to his own country. In I9II appeared a fine volume on "Les Végétaux houillers recueillis dans le Hainaut Belge" containing various new genera and species. Another foreign work was his joint book with Dr. Jongmans on the Calamites of Western Europe, published by the Dutch Government. This is a huge monograph; the Atlas published in $\mathrm{r}_{9} \mathbf{5}$ contains $x_{5} 8$ fine plates. So far as the writer is aware, only a portion of the text has appeared.

It remains to notice briefly some of Kidston's work in conjunction with other botanists. One of his most valued colleagues was the late Prof. D. T. GwynneVaughan, whose early death was so severe a loss to botany. Their work on the fossil Osmundaceæ, in five parts, ranging from 1907 to $\mathrm{rgI}_{4}$, is a palæobotanical classic, tracing back the history of the Royal ferns from the Tertiary to the Permian. An admirable photograph is extant, showing the two collaborators at work together on this investigation. Other papers with Gwynne-Vaughan were on a Tempskya from Russia, by far the best account up to that time of this peculiar type of fern-stem, and on a Lower Carboniferous fossil, Stenomyelon tuedianum, discovered by Kidston. This is a model of anatomical work, concise, clear, and exhaustive.

Kidston's work in conjunction with Prof. W. H. Lang, on the Old Red Sandstone plants of the Rhynie Chert-bed (five memoirs, I9I7-I921), was the most important of all, for it demonstrated, in full detail, the structure of the oldest land-plants of which we have any certain knowledge. Never was a great discovery more completely and wisely expounded. The simple plants of Rhynie, thanks to Kidston and Lang's researches, now form the basis of evolutionary work on the plant kingdom.

Other joint memoirs by the same authors were on Hicklingia, a new genus of Early Devonian Plants (1923), and on Palcopitys Milleri (1923), the famous but long neglected "cone-bearing tree" of Hugh Miller. The authors worked out the structure fully, but reserved judgment on the affinities of the plant, which is certainly of astonishingly high organisation for an Early Devonian horizon.

Kidston, at the time of his death, was engaged on what, from a floristic point of view, was to have been the greatest work of his career. This was nothing less than the full description and illustration of all the Carboniferous plants of Great Britain. The series, published by the Geological Survey, was planned to consist of ten memoirs but would, no doubt, have run to more. Four memoirs have been actually published, illustrated by $9 \mathrm{r}$ fine plates. They only embrace a portion of the ferns and fern-like plants. The systematic descriptions are illuminated by admirable observations on broader questions of affinity. It is understood that two more parts are sufficiently advanced for publication, and it is earnestly to be hoped that this magnificent work, a credit alike to the author and to the Department which undertook it, may eventually be brought to completion.

Kidston, among his other accomplishments, was a highly skilled photographer and was thus enabled to illustrate his own works, both systematic and anatomical, in a manner which adds immensely to their value and beauty. In all his writings Kidston showed himself a most fair and generous critic. His splendid collections both of impressions and sections were always available for the use of his scientific colleagues. The present writer, in particular, can testify how much he owes to the constant and generous help of his old friend.

D. H. S.

Prof. Alois Mrazek.

ON November 26, I923, died Dr. Mrázek, professor of zoology in the Charles' (Bohemian) University of Prague. He was born in I868 in Príbram, and originally worked under A. Fric in the patriotic study of the fauna, the aim of which was to increase the knowledge of Bohemian fauna and the extension of the single genera. Later on, under the influence of his second teacher, Prof. Vejdovsky, he devoted his study to typical problems of the period of classical morphology and cytology. He did not limit himself only to the discovery and description of new genera, but he was also interested in the problems, which are typical for the area, of the classical morphology and cytology.

Mrázek directed his study chiefly to the Crustacea and Copepoda, especially to the hermaphroditism of the first and the numerous anatomical details of the antennæ of the second, and the exactness of his work became known in foreign countries, from which valuable material was entrusted to him for research. $\mathrm{He}$ found cystercoids in copepods, and their study brought him to that of the complicated cycles of the evolution of helminthes, and so he became a co-editor of the Journal of Parasitology and a member of the Helminthological Society of Washington. $\mathrm{He}$ investigated also the Sporozoa, Planariæ, Oligochæta, and studied very deeply the life of ants, all work of great exactitude, and discovered fresh-water Nemertines in Bohemia, as well as the only representative of subtropical Temnocephalids in the Lake of Scutari. His beautiful drawings appear frequently in the larger works on cytology. Mrázek was a modern zoologist who was a master of the problems of his time, not a one-sided systematist or a mere morphologist. His work touched also problems of variability, heredity of acquired characters, regeneration, and he devoted a good deal of his time to the study of the relations between the organism and the medium in which it lives, to ecology.

Mrázek was a splendid teacher, full of sacrifice, especially in laboratory work. He published a series of popular lectures on the theory of evolution, and translated Romanes' work, "Darwin and after Darwin." He founded a small but pretty aquarium in his institute, which is visited by thousands of students and other people. While still living, he presented to his institute his rich private library and all his instruments, etc. He was a member of the Bohemian Academy of Science and of the Royal Society of Bohemia. His death is a great loss to our University.

\section{Bohuslav Brauner.}

WE much regret to announce the death of Prof. P. Natorp, emeritus professor of philosophy in the University of Marburg, author of "The Logical Foundations of the Exact Sciences," and leader of the neo-Kantian school, aged seventy. 